\title{
Debt Overhang, Gazelles' Growth, and Fiscal Policy: A Note from the Quantile Regression Approach
}

\author{
Sorin Gabriel Anton ${ }^{1, * \mathbb{D}}$, Mihaela Onofrei ${ }^{1}$, Emilia Gogu ${ }^{2}$, Bogdan Constantin Neculau ${ }^{3}$ and Florin Mihai ${ }^{4}(\mathbb{D}$ \\ 1 Finance, Money and Public Administration Department, Faculty of Economics and Business Administration, \\ Alexandru Ioan Cuza University of Iași, 700506 Iași, Romania; onofrei@uaic.ro \\ 2 Statistics and Econometrics Department, Faculty of Economic Cybernetics, Statistics and Informatics, \\ Bucharest University of Economic Studies, 010552 București, Romania; emilia.gogu@csie.ase.ro \\ 3 Faculty of Psychology and Educational Sciences, Alexandru Ioan Cuza University of Iași, \\ 700506 Iași, Romania; neculau@uaic.ro \\ 4 Management Information Systems Department, Faculty of Accounting Management Information Systems, \\ Bucharest University of Economic Studies, 010552 București, Romania; florin.mihai@cig.ase.ro \\ * Correspondence: sorin.anton@uaic.ro
}

Citation: Anton, S.G.; Onofrei, M.; Gogu, E.; Neculau, B.C.; Mihai, F. Debt Overhang, Gazelles' Growth, and Fiscal Policy: A Note from the Quantile Regression Approach. Sustainability 2021, 13, 10457. https:/ / doi.org/10.3390/su131810457

Academic Editor: Klaus Reiner Schenk-Hoppé

Received: 15 August 2021

Accepted: 16 September 2021

Published: 20 September 2021

Publisher's Note: MDPI stays neutral with regard to jurisdictional claims in published maps and institutional affiliations.

Copyright: (c) 2021 by the authors. Licensee MDPI, Basel, Switzerland. This article is an open access article distributed under the terms and conditions of the Creative Commons Attribution (CC BY) license (https:// creativecommons.org/licenses/by/ $4.0 /)$.

\begin{abstract}
The paper aims to examine the relationship between leverage and firm growth and the impact of fiscal policy on this relationship using a panel data quantile regression approach. Employing a sample of gazelles from emerging Europe for the 2006-2014 period, we find that debt overhang negatively affects firm growth only for the lower growth quantiles. In addition, we found that the negative effect is higher for the gazelles located in countries with lower corporate income effective tax rates. However, for the higher growth quantiles, the impact of debt on firm growth is positive and statistically significant. Our results reconcile the mixed results of the previous studies and have practical implications for financing strategies in emerging markets.
\end{abstract}

Keywords: leverage; sales growth; gazelles; emerging economies; fiscal policy; quantile regression

\section{Introduction}

Over the last decade high-growth firms (HGFs) and gazelles, as a subset of HGFs, attracted significant attention from researchers and also from policymakers from the European Union [1], OECD countries [2] and developing countries [3]. In this paper, we use the definition provided by Eurostat-OECD for gazelles: "the subset of high-growth enterprises which are up to five years old" ([4] p. 63). HGFs represent "all enterprises with average annualized growth greater than $20 \%$ per annum, over a three year period" ([4] p. 61). In our case, the gazelles' growth is measured as turnover growth.

Numerous strategies (e.g., Europe 2020 strategy) and public policies have been implemented to support this type of firm all over the world. As argued by Brown, Mawson, and Mason [5], at the heart of these public policies stayed the financial support for HGFs, as these firms tend to be more financially constrained in the EU [6], and their access to finance has a significant effect on their performance. However, despite the importance of gazelles for new job creation in the private sector in the developed [7] and in the developing economies alike [3,8], innovation processes [9], economic growth, and structural changes in emerging markets [10], little is known about the impact of financing decision on the gazelles' or HGSs' performance [11] and how fiscal policy affects this decision.

The paper aims to study the impact of leverage on firm growth (measured as sales growth) using data for the period from 2006-2014 for a large data set of gazelles located in Central, Eastern, and Southeastern European (CESEE) countries. Our sample represents an interesting framework to analyze the impact of debt overhang on firm growth during and after the period of high growth. Contrary to previous studies that reported either negative influence, or positive influence on firm growth, our results show a non-linear influence. 
Debt overhang negatively affects firm growth only for the lower growth quantiles, while, for the higher growth quantiles, the impact of debt on firm growth is positive and statistically significant. In addition, we found that the negative effect is higher for the gazelles located in countries with lower corporate income effective tax rates. We further conduct a series of robustness checks, and our results hold irrespective of the different measures of firm size and different samples we use.

The paper contributes to the existing literature in several ways. Firstly, contrary to the previous paper, which employed mean regression techniques to test the relationship between leverage and firm growth, our paper uses a more suitable approach through quantile regression. This approach offers a more detailed image of the different impacts of the independent variables on dependent variables [12-15] and accounts for heterogeneity and non-Gaussian distributions, which characterize firm growth data [16]. Employing a quantile regression technique makes it possible to differentiate the effect of debt based on the distribution of the value of the sales growth rate. Hence, our results provide empirical evidence for a non-linear relationship between leverage and firm growth. Secondly, we study the relationship between leverage and firm growth for a sample of gazelles located in emerging countries with a bank-based system. Gazelles represent an interesting framework to study the firm growth process given the unique management challenges [11] and also because they attained high growth. Thirdly, our study employs a large cross-country sample of gazelles for a long period, comprising both economic growth and downturn when financing and fiscal policies experienced different behaviour. Fourthly, unlike previous studies, we control for the effects of macroeconomic uncertainty and the level of financial development on firm growth. Fifthly, we show how fiscal policy affects the relationship between leverage and firm growth.

The remainder of the paper is organized as follows: Section 2 presents a brief literature review. Section 3 describes the data and methodology employed in the paper. Section 4 presents the main findings and verifies the robustness of the results. Section 5 concludes the research.

\section{Literature Review}

As financing decisions have significant effects on firm growth, the relationship between leverage and firm growth has been extensively researched. However, most of the previous studies used mean regression approaches and focused on large publicly traded manufacturing firms [17] and small and medium-sized enterprises (SMEs) from developed economies [18,19]. With a few exceptions [20-22], research that examines how financial access and capital structure decisions impact the performance of HGFs is, however, still in its infancy and focuses mostly on firms located in the developed economies [5].

The results of the empirical studies on the relationship between leverage and firm growth are mixed. Most of the empirical studies found a positive relationship between leverage and firm growth $[18,20,23,24]$, but other studies indicate a negative impact of leverage on firm growth $[19,22,25,26]$. Employing a sample of Swedish micro and small firms over the period from 1993-1998, Heshmati [18] found a positive relationship between debt-equity ratios and sales growth. A similar positive relationship between leverage and sales growth has been found by Honjo \& Harada [19] on a sample of Japanese SMEs. Employing a large sample of 4928 privately held firms from the US over the period from 2005-2012, Cole \& Sokolyk [24] found that business bank credit is positively associated with revenue growth and firm survival.

On the other hand, analyzing the determinants of fast growth on a sample of Spanish firms, Lopez-Garcia \& Puente [21] show that leverage may negatively affect firm growth. Similar findings have been reported by Le and Phan [26] for a sample of Vietnamese non-financial listed firms during the period from 2007 to 2012.

Regarding the firms located in emerging Europe, most of the previous studies focused on the effect of access to finance on entrepreneurship, SMEs' growth $[27,28]$, and listed firm growth. Access to finance is considered in the extant literature to be one of the most binding 
constraints on firm growth in developing countries [29]. Hashi and Krasniqi [27] found that external financing constraints represent a growth determinant of SMEs in advanced transition economies (Poland, Hungary, and the Czech Republic). In addition, Botrić and Božić [28] state that the issue of access to finance in post-transition EU member countries is "potentially harmful to the development of entrepreneurship, innovation performance, and overall growth" ([28], p. 129). Mateev and Anastasov [20] employed a large sample of fast-growing SMEs operating in six CEE countries before the latest global financial crisis (over the period from 2001-2005) and provided empirical evidence for a positive impact of leverage on sales growth. In a similar study, Damijan [30] used a more recent period (2005-2014) and showed that debt hurts total factor productivity, employment, and investment growth. Furthermore, their results show that this effect is more pronounced in the case of SMEs.

Pirtea et al. [31] reported a non-linear and negative relation between debt ratio and profitability for the Romanian public firms, which support the pecking order theory. Employing a large sample of public firms from Eastern Europe over the period from 2004-2017, Botta [32] found that a higher-than-optimal level of leverage harms capital expenditure and returns. None of these studies tested the role of fiscal policy on the relationship between leverage and firm growth.

\section{Data and Empirical Methodology}

The research uses firm-level data retrieved from the Amadeus database and countrylevel data from the World Bank. According to Eurostat-OECD [4], gazelles are firms up to five years old, with at least 10 employees in the starting year (2006 in our case), and an average annualized growth exceeding $20 \%$ over a 3-year period (2007-2009). Firm growth can be measured by the number of employees and by turnover, the latter indicator being preferred as it captures both short- and long-term performance [33]. After usual cleaning procedures have been applied (we exclude firms from the financial intermediation sector and insurance industries (NACE codes 64-66); we eliminate observations with negative assets and negative sales; we also eliminate firms that did not have complete records on our main regression variables), the final sample comprises 1105 gazelles from 15 CESEE countries (Bosnia and Herzegovina, Bulgaria, Croatia, Czech Republic, Estonia, Hungary, Latvia, Lithuania, Macedonia, Poland, Romania, Serbia, Slovak Republic, Slovenia, and Ukraine) and 9295 firm-year observations.

In the extant literature, the estimates of leverage effect on firm growth are usually based on mean regression techniques, which have never been satisfactory approaches when considering heterogeneous populations [34]. We employ the quantile regression (hereafter, QR) since it offers a more detailed picture of the relationship between leverage and firm growth. Furthermore, this approach accounts for heterogeneity and non-Gaussian distributions, which characterize firm growth data [16]. Given their advantages, numerous firm growth studies recently employed quantile regression techniques [35-39].

We use the QR approach developed by Koenker \& Hallock [40], with the following specification:

$$
y_{i t}=\beta_{0}+x_{i, t}^{\prime} \beta_{\theta 1}+\varepsilon_{\theta i, t}
$$

with:

$$
\operatorname{Quant}_{\theta}\left(y_{i, t} \mid x_{i, t}\right)=\beta_{0}+x_{i, t}^{\prime} \beta_{\theta 1}
$$

with the following restriction:

$$
\operatorname{Quant}_{\theta}\left(\varepsilon_{\theta i, t} \mid x_{i, t}\right)=0
$$

where $y_{i, t}$ represents the dependent variable (firm growth), $x_{i, t}$ represents a vector of regressors, $\beta_{\theta 1}$ is the vector of parameters to be estimated, $\varepsilon_{\theta i, t}$ is the error, $i$ denotes firm $(i=1, \ldots, 1.105)$, and $t$ denotes time $(t=1, \ldots, 9)$. Quant ${ }_{\theta}\left(y_{i, t} \mid x_{i, t}\right)$ denotes the $\theta$ th conditional quantile of $y_{i, t}$ given $x_{i, t}$. Standard errors are based on the bootstrap method with 1000 replications. 
The dependent variable for firm growth (GROW) is computed as the logarithmic difference in sales in two consecutive years in line with prior studies [35]. The vector $X$ includes firm-specific variables, namely leverage $\left(\mathrm{LEV}_{\mathrm{i}, \mathrm{t}-1}\right)$, age $\left(\mathrm{AGE}_{\mathrm{i}, \mathrm{t}-1}\right)$, size $\left(\mathrm{SIZ}_{\mathrm{i}, \mathrm{t}-1}\right)$, liquidity $\left(\mathrm{LIQ}_{\mathrm{i}, t-1}\right)$, and labour productivity $\left(\mathrm{LAP}_{\mathrm{i}, \mathrm{t}-1}\right)$ following relevant studies on firm growth. Firm-level explanatory variables are lagged 1 year to clarify the causality relationship. Unlike prior research, we include in the explanatory variables macroeconomic and banking sector variables, namely, economic growth $\left(\mathrm{ECG}_{\mathrm{j}, \mathrm{t}}\right)$, economic development $\left(E C D_{j, t}\right)$, and financial development $\left(\mathrm{FID}_{\mathrm{j}, \mathrm{t}}\right)$. Table 1 provides the definitions of the variables used throughout the panel quantile regression. All nominal values are deflated by the CPI index using 2000 as a base year.

Table 1. Variable descriptions.

\begin{tabular}{cc}
\hline Dependent Variable & Description \\
\hline Firm growth (GROW) & Log $\left(\right.$ sales $\left._{\mathrm{i}, \mathrm{t}}\right)-\log \left(\mathrm{sales}_{\mathrm{i}, \mathrm{t}-1}\right)$ \\
Independent variables & \\
Leverage (LEV) & Total debt/Total assets \\
Age (AGE) & Log of firm age \\
Size (SIZ) & Log of total assets \\
Liquidity (LIQ) & Current assets /Current liabilities \\
Labour productivity (LAP) & Log of (total sales/number of employees) \\
Economic growth (ECG) & GDP growth(annual \%) \\
Economic development (ECD) & Log of GDP per capita \\
Financial development (FID) & Private credit to GDP(\%) \\
\hline
\end{tabular}

In the second part of our empirical analysis, we test whether the fiscal policy has any impact on the relationship between leverage and firm growth. We split our sample into two parts based on the level of the total tax rate (\% of commercial profits) provided by the World Bank (Doing Business Report). The total tax rate is computed as actual tax payable divided by commercial profit. The median value recorder for this variable in our sample $(45.6 \%)$ was used to divide countries into lower and higher corporate income tax rates (effective).

\section{Empirical Results}

Table 2 presents the descriptive statistics and the correlation coefficients among the variables. Outliers have been eliminated by winsorizing the observations in the top and bottom 1 percentile for independent financial variables before presenting the summary statistics. On average, sales increased by 12\% per year over the period 2006-2014 despite the unstable economic environment. It is worth noting that the mean value of leverage is quite high (0.82), suggesting that debt is largely used by gazelles to finance growth, a result consistent with the pecking-order theory.

Table 2. Summary statistics and correlation matrix.

\begin{tabular}{|c|c|c|c|c|c|c|c|c|c|c|c|c|c|}
\hline Variable & Mean & Std. Dev. & Min & Max & GROW & LEV & AGE & SIZ & LIQ & LAP & ECG & ECD & FID \\
\hline GROW & 0.120 & 0.856 & -8.364 & 8.893 & 1.00 & & & & & & & & \\
\hline LEV & 0.822 & 0.630 & 0.013 & 4.699 & -0.09 & 1.00 & & & & & & & \\
\hline AGE & 1.518 & 0.612 & 0.000 & 2.303 & -0.36 & 0.00 & 1.00 & & & & & & \\
\hline SIZ & 13.867 & 2.049 & 3.636 & 20.784 & 0.06 & -0.16 & 0.13 & 1.00 & & & & & \\
\hline LIQ & 2.094 & 3.435 & 0.060 & 25.630 & -0.06 & -0.31 & 0.06 & -0.05 & 1.00 & & & & \\
\hline LAP & 10.385 & 1.455 & 2.593 & 16.934 & 0.19 & -0.09 & 0.00 & 0.57 & -0.08 & 1.00 & & & \\
\hline ECG & 1.904 & 5.250 & -14.814 & 11.902 & 0.17 & -0.02 & -0.26 & -0.03 & -0.02 & 0.09 & 1.00 & & \\
\hline ECD & 8.917 & 0.646 & 7.742 & 10.222 & -0.03 & -0.07 & 0.08 & 0.09 & -0.04 & 0.26 & 0.19 & 1.00 & \\
\hline FID & 51.564 & 16.847 & 21.218 & 102.531 & -0.11 & 0.01 & 0.25 & 0.03 & 0.06 & -0.09 & -0.50 & -0.46 & 1.00 \\
\hline
\end{tabular}

Notes: GROW stands for firm growth; LEV the leverage; AGE the firm age; SIZ the firm size; LIQ the liquidity; LAP the labour productivity; ECG the economic growth; ECD the economic development; FID the financial development. 
We notice a negative correlation between leverage and firm growth. As the coefficients are not high, we consider that multicollinearity is unlikely to be an issue in our estimations.

Table 3 reports quantile regression results along with ordinary least squares (OLS) regression results for the full sample. We introduce mean regression (OLS) only as a benchmark. We consider that OLS estimation is quite misleading as it predicts a negative relationship between leverage and firm growth, but this occurs only at the left-hand side of the firm growth distribution.

Table 3. Multiple regression.

\begin{tabular}{|c|c|c|c|c|c|c|c|c|c|c|}
\hline & OLS & q10 & q20 & q30 & $\mathrm{q} 40$ & q50 & q60 & q70 & q80 & q90 \\
\hline LEV & $\begin{array}{l}-0.0308^{*} \\
(-0.0171)\end{array}$ & $\begin{array}{c}-0.1771^{* * *} \\
(-0.0378)\end{array}$ & $\begin{array}{c}-0.0643^{* * *} \\
(-0.0164)\end{array}$ & $\begin{array}{c}-0.0175 \\
(-0.0119)\end{array}$ & $\begin{array}{c}0.0001 \\
(-0.0103)\end{array}$ & $\begin{array}{c}0.0113 \\
(-0.0088)\end{array}$ & $\begin{array}{l}0.0212 * * \\
(-0.0102)\end{array}$ & $\begin{array}{l}0.0374^{* * *} \\
(-0.0113)\end{array}$ & $\begin{array}{l}0.0746^{* * *} \\
(-0.0156)\end{array}$ & $\begin{array}{l}0.1481^{* * *} \\
(-0.0267)\end{array}$ \\
\hline AGE & $\begin{array}{c}-0.4418^{* * *} \\
(-0.0157)\end{array}$ & $\begin{array}{c}-0.3215^{* * *} \\
(-0.0348)\end{array}$ & $\begin{array}{c}-0.2436^{* * *} \\
(-0.0151)\end{array}$ & $\begin{array}{c}-0.2310^{* * *} \\
(-0.0109)\end{array}$ & $\begin{array}{c}-0.2546^{* * *} \\
(-0.0095)\end{array}$ & $\begin{array}{c}-0.2845^{* * *} \\
(-0.008)\end{array}$ & $\begin{array}{c}-0.3212 * * * \\
(-0.0093)\end{array}$ & $\begin{array}{c}-0.3511^{* * *} \\
(-0.0103)\end{array}$ & $\begin{array}{c}-0.4191 * * * \\
(-0.0144)\end{array}$ & $\begin{array}{c}-0.5468 * * * \\
(-0.0245)\end{array}$ \\
\hline SIZ & $\begin{array}{l}0.0864^{* * *} \\
(-0.0055)\end{array}$ & $\begin{array}{l}0.0769 * * * \\
(-0.0123)\end{array}$ & $\begin{array}{l}0.0579 * * * \\
(-0.0053)\end{array}$ & $\begin{array}{l}0.0463^{* * *} \\
(-0.0039)\end{array}$ & $\begin{array}{l}0.0416^{* * *} \\
(-0.0034)\end{array}$ & $\begin{array}{l}0.0394 * * * \\
(-0.0028)\end{array}$ & $\begin{array}{l}0.0417^{* * *} \\
(-0.0033)\end{array}$ & $\begin{array}{l}0.0421 * * * \\
(-0.0037)\end{array}$ & $\begin{array}{l}0.0428^{* * *} \\
(-0.0051)\end{array}$ & $\begin{array}{l}0.0616^{* * *} \\
(-0.0087)\end{array}$ \\
\hline LIQ & $\begin{array}{l}-0.0062 \\
(-0.0028)\end{array}$ & $\begin{array}{c}-0.0297 * * * \\
(-0.0063)\end{array}$ & $\begin{array}{c}-0.0075^{* * *} \\
(-0.0027)\end{array}$ & $\begin{array}{c}-0.003 \\
(-0.002)\end{array}$ & $\begin{array}{l}-0.0024 \\
(-0.0017)\end{array}$ & $\begin{array}{l}-0.0008 \\
(-0.0015)\end{array}$ & $\begin{array}{l}-0.0007 \\
(-0.0017)\end{array}$ & $\begin{array}{c}-0.001 \\
(-0.0019)\end{array}$ & $\begin{array}{c}0.0009 \\
(-0.0026)\end{array}$ & $\begin{array}{c}0.0052 \\
(-0.0044)\end{array}$ \\
\hline LAP & $\begin{array}{c}-0.1761^{* * *} \\
(-0.0077)\end{array}$ & $\begin{array}{c}-0.1116^{* * *} \\
(-0.017)\end{array}$ & $\begin{array}{c}-0.0749^{* * *} \\
(-0.0074)\end{array}$ & $\begin{array}{c}-0.0625^{* * *} \\
(-0.0054)\end{array}$ & $\begin{array}{c}-0.0617 * * * \\
(-0.0046)\end{array}$ & $\begin{array}{c}-0.0670 * * * \\
(-0.0039)\end{array}$ & $\begin{array}{c}-0.0726^{* * *} \\
(-0.0046)\end{array}$ & $\begin{array}{c}-0.0798 \text { *** } \\
(-0.0051)\end{array}$ & $\begin{array}{c}-0.1005^{* * *} \\
(-0.007)\end{array}$ & $\begin{array}{c}-0.1532 * * * \\
(-0.012)\end{array}$ \\
\hline ECG & $\begin{array}{l}0.0142 * * * \\
(-0.0019)\end{array}$ & $\begin{array}{l}0.0135^{* * *} \\
(-0.0043)\end{array}$ & $\begin{array}{l}0.0154 * * * \\
(-0.0019)\end{array}$ & $\begin{array}{l}0.0170^{* * *} \\
(-0.0013)\end{array}$ & $\begin{array}{l}0.0172 * * * \\
(-0.0012)\end{array}$ & $\begin{array}{l}0.0167 * * * \\
(-0.001)\end{array}$ & $\begin{array}{l}0.0152 * * * \\
(-0.0012)\end{array}$ & $\begin{array}{l}0.0150 * * * \\
(-0.0013)\end{array}$ & $\begin{array}{l}0.0159 * * * \\
(-0.0018)\end{array}$ & $\begin{array}{c}0.0191^{* * *} \\
(-0.003)\end{array}$ \\
\hline ECD & $\begin{array}{l}0.0754^{* * *} \\
(-0.0163)\end{array}$ & $\begin{array}{l}0.1769 * * * \\
(-0.0362)\end{array}$ & $\begin{array}{l}0.0941 * * * \\
(-0.0157)\end{array}$ & $\begin{array}{l}0.0581 * * * \\
(-0.0114)\end{array}$ & $\begin{array}{l}0.0371 * * * \\
(-0.0099)\end{array}$ & $\begin{array}{c}0.0135 \\
(-0.0084)\end{array}$ & $\begin{array}{c}0.0037 \\
(-0.0097)\end{array}$ & $\begin{array}{l}-0.0205^{*} \\
(-0.0108)\end{array}$ & $\begin{array}{l}-0.0346^{* *} \\
(-0.0149)\end{array}$ & $\begin{array}{l}-0.0452 * \\
(-0.0255)\end{array}$ \\
\hline FID & $\begin{array}{l}0.0015^{* *} \\
(-0.0007)\end{array}$ & $\begin{array}{c}0.0003 \\
(-0.0016)\end{array}$ & $\begin{array}{c}0.0005 \\
(-0.0007)\end{array}$ & $\begin{array}{c}0.0007 \\
(-0.0005)\end{array}$ & $\begin{array}{l}0.0013^{* * *} \\
(-0.0004)\end{array}$ & $\begin{array}{l}0.0011^{* * *} \\
(-0.0004)\end{array}$ & $\begin{array}{l}0.0011^{* * *} \\
(-0.0004)\end{array}$ & $\begin{array}{l}0.0011^{* *} \\
(-0.0005)\end{array}$ & $\begin{array}{l}0.0014^{* *} \\
(-0.0007)\end{array}$ & $\begin{array}{c}0.0021 * \\
(-0.0011)\end{array}$ \\
\hline Constant & $\begin{array}{l}0.6223 * * * \\
(-0.1689)\end{array}$ & $\begin{array}{c}-1.3475 * * * \\
(-0.3743)\end{array}$ & $\begin{array}{c}-0.6921 \text { *** } \\
(-0.1626)\end{array}$ & $\begin{array}{l}-0.2717^{* *} \\
(-0.1179)\end{array}$ & $\begin{array}{c}0.0589 \\
(-0.1022)\end{array}$ & $\begin{array}{l}0.4828^{* * *} \\
(-0.0866)\end{array}$ & $\begin{array}{l}0.7238 * * * \\
(-0.1006)\end{array}$ & $\begin{array}{l}1.1436^{* * *} \\
(-0.1113)\end{array}$ & $\begin{array}{l}1.6635^{* * *} \\
(-0.1545)\end{array}$ & $\begin{array}{l}2.3658^{* * *} \\
(-0.2639)\end{array}$ \\
\hline $\begin{array}{l}\text { R2/Pseudo } \\
\text { R2 }\end{array}$ & 0.158 & 0.0543 & 0.0582 & 0.0594 & 0.0669 & 0.0815 & 0.0983 & 0.1196 & 0.1433 & 0.1845 \\
\hline N. of cases & 7730 & 7730 & 7730 & 7730 & 7730 & 7730 & 7730 & 7730 & 7730 & 7730 \\
\hline
\end{tabular}

Notes: Bootstrapped SEs (1000 reps) are shown in parentheses. ${ }^{* *}$ Stands for significant coefficient at $1 \%$ level, ${ }^{* *}$ at $5 \%$, and ${ }^{*}$ at $10 \%$. GROW stands for firm growth; LEV the leverage; AGE the firm age; SIZ the firm size; LIQ the liquidity; LAP the labour productivity; ECG the economic growth; ECD the economic development; FID the financial development.

Our empirical results show that the effect of financial leverage on firm growth is not homogeneous among various quantile levels (see also Figure 1). We find that leverage has a significantly negative effect on firm growth from the 0.10 to the 0.20 quantiles, a result consistent with the trade-off theory and with the results reported by other studies $[16,17,19,21]$. The high level of debt reported by gazelles in emerging Europe hampers firm growth due to potential underinvestment incentives [41,42].

However, the effect becomes significantly positive for quantiles between 0.60 and 0.90 (i.e., extremely high growing firms). The effect of leverage on firm growth is insignificant for gazelles at the middle-range quantiles (i.e., from 0.30 to 0.50 ). These results imply that debt has positive effects on firm growth and may be used to finance new investments (which spur sales) only when the firm has already a high growth pattern.

Regarding firm characteristics, our results in Table 3 are in line with those reported by other empirical papers focused on SMEs. For example, we find that younger firms tend to grow faster than older ones and larger firms experience higher turnover growth. Labour productivity has a negative impact on firm growth for all quantiles, while the negative relationship between liquidity and sales growth is statistically significant only at low quantiles of GROW (Q10 and Q20).

Contrary to the previous papers, our results show that the macroeconomic environment and financial development are important determinants of firm growth. The relationship between economic development and firm growth varies widely depending on the quantile level of GROW. The effect of economic development is significantly positive (negative) when the quantile of GROW is between 0.10 and 0.40 (between 0.70 and 0.90 ). The effect of economic growth on sales growth is positive and statistically significant for all quantiles, suggesting that greater economic demand partially explains sales growth. Our results show that the financial development of a country has a positive effect on firm growth, but this effect is found only at higher GROW quantiles (from 0.40 to 0.90 ). This 
result reconciles the conflicting findings from the extant literature on the impact of financial development on firm growth.
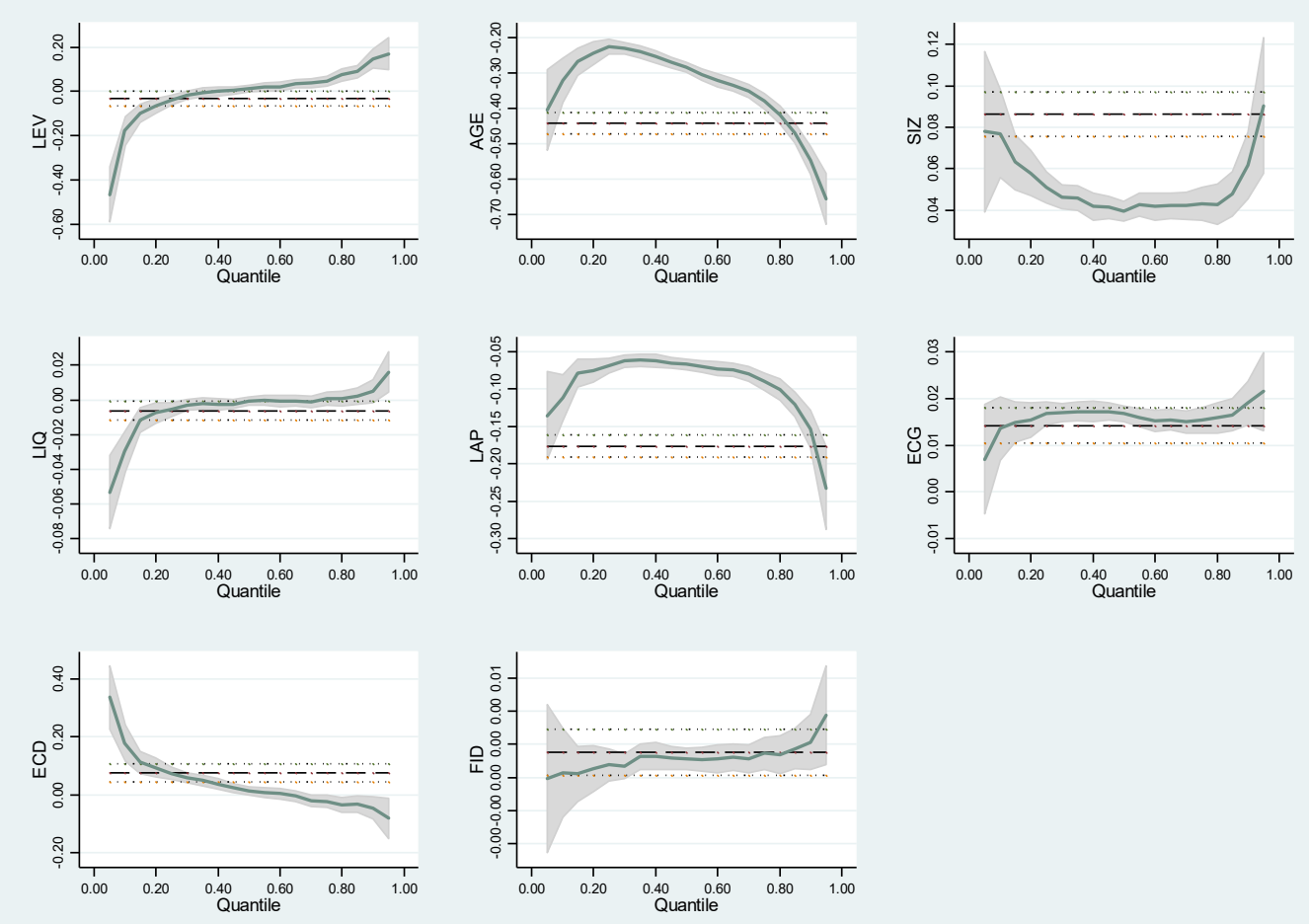

Figure 1. Quantile regression coefficients. Notes: LEV stands for the leverage; AGE the firm age; SIZ the firm size; LIQ the liquidity; LAP the labour productivity; ECG the economic growth; ECD the economic development; FID the financial development.

In the second part of our empirical analysis, we test whether the fiscal policy has any impact on the relationship between leverage and firm growth. We ran our models once again on the first subsample of gazelles that are active in countries with lower corporate income effective tax rates.

The results of the quantile regression (presented in Table 4) support only some of the previous findings. Contrary to the results, we find that leverage has a significantly negative effect on firm growth from the 0.10 to the 0.30 quantiles, while the effect becomes significantly positive for quantiles between 0.70 and 0.90 (i.e., extremely high growing firms). We notice that the negative effect is higher for the gazelles located in countries with lower corporate income effective tax rates.

The sign and significance of other firm-level variables (age, size, and labour productivity) remain broadly the same. However, it is worth noticing that the coefficient for labour productivity is lower for gazelles active in countries with lower profit taxes. Another significant difference is related to the impact of liquidity on firm growth. In the case of firms active in countries with lower profit tax, liquidity has a negative and statistically significant effect on sales growth only for the 0.10 quantile.

With one exception (economic growth), the impact of macroeconomic economic and financial development on firm growth is different for gazelles located in countries with lower corporate income effective tax rates. The relationship between economic development and firm growth varies widely depending on the quantile level of GROW. The effect of economic development is significantly positive when the quantile of GROW is between 0.10 and 0.50 . In addition, our results show that the financial development of a country has a positive effect on firm growth, but this effect is found only at higher GROW quantiles (from 0.30 to 0.90 ) with the level of significance at $5 \%$. This result reconciles the conflicting findings from the extant literature on the impact of financial development on firm growth. 
Table 4. Multiple regression (sample of gazelles active in countries with lower corporate income effective tax rates).

\begin{tabular}{|c|c|c|c|c|c|c|c|c|c|c|}
\hline & OLS & q10 & q20 & q30 & $\mathrm{q} 40$ & q50 & $q 60$ & q70 & q80 & q90 \\
\hline LEV & $\begin{array}{c}-0.0589 * * * \\
(0.0204)\end{array}$ & $\begin{array}{c}-0.3471 * * * \\
(0.0507)\end{array}$ & $\begin{array}{c}-0.1014^{* * *} \\
(0.0227)\end{array}$ & $\begin{array}{c}-0.0308^{* *} \\
(0.0154)\end{array}$ & $\begin{array}{l}-0.0211 \\
(0.0128)\end{array}$ & $\begin{array}{c}0.0084 \\
(0.0118)\end{array}$ & $\begin{array}{c}0.0145 \\
(0.0134)\end{array}$ & $\begin{array}{c}0.0284^{* *} \\
(0.0134)\end{array}$ & $\begin{array}{c}0.0718^{* * *} \\
(0.0198)\end{array}$ & $\begin{array}{c}0.1451^{* * *} \\
(0.0339)\end{array}$ \\
\hline AGE & $\begin{array}{c}-0.4128^{* * *} \\
(0.0200)\end{array}$ & $\begin{array}{c}-0.3574^{* * *} \\
(0.0497)\end{array}$ & $\begin{array}{c}-0.2556^{* * *} \\
(0.0222)\end{array}$ & $\begin{array}{c}-0.2343^{* * *} \\
(0.0151)\end{array}$ & $\begin{array}{c}-0.2536^{* * *} \\
(0.0126)\end{array}$ & $\begin{array}{c}-0.2823 * * * \\
(0.0116)\end{array}$ & $\begin{array}{c}-0.3069^{* * *} \\
(0.0131)\end{array}$ & $\begin{array}{c}-0.3275^{* * *} \\
(0.0131)\end{array}$ & $\begin{array}{c}-0.3783^{* * *} \\
(0.0195)\end{array}$ & $\begin{array}{c}-0.4810^{* * *} \\
(0.0332)\end{array}$ \\
\hline SIZ & $\begin{array}{c}0.0621 * * * \\
(0.0073)\end{array}$ & $\begin{array}{c}0.0842 * * * \\
(0.0182)\end{array}$ & $\begin{array}{c}0.0546 \text { *** } \\
(0.0081)\end{array}$ & $\begin{array}{c}0.0430 * * * \\
(0.0055)\end{array}$ & $\begin{array}{c}0.0366^{* * *} \\
(0.0046)\end{array}$ & $\begin{array}{c}0.0346^{* * *} \\
(0.0042)\end{array}$ & $\begin{array}{c}0.0294 * * * \\
(0.0048)\end{array}$ & $\begin{array}{c}0.0301 * * * \\
(0.0048)\end{array}$ & $\begin{array}{c}0.0297 * * * \\
(0.0071)\end{array}$ & $\begin{array}{c}0.0336^{* * *} \\
(0.0121)\end{array}$ \\
\hline LIQ & $\begin{array}{l}-0.0021 \\
(0.0042)\end{array}$ & $\begin{array}{c}-0.0260 \text { ** } \\
(0.0103)\end{array}$ & $\begin{array}{l}-0.0041 \\
(0.0046)\end{array}$ & $\begin{array}{l}-0.0024 \\
(0.0031)\end{array}$ & $\begin{array}{l}-0.0036 \\
(0.0026)\end{array}$ & $\begin{array}{c}0.0027 \\
(0.0024)\end{array}$ & $\begin{array}{c}0.0022 \\
(0.0027)\end{array}$ & $\begin{array}{c}0.0007 \\
(0.0027)\end{array}$ & $\begin{array}{c}0.0023 \\
(0.0040)\end{array}$ & $\begin{array}{c}0.0035 \\
(0.0069)\end{array}$ \\
\hline LAP & $\begin{array}{c}-0.1301 * * * \\
(0.0102)\end{array}$ & $\begin{array}{c}-0.1421^{* * *} \\
(0.0252)\end{array}$ & $\begin{array}{c}-0.0863^{* * *} \\
(0.0113)\end{array}$ & $\begin{array}{c}-0.0671^{* * *} \\
(0.0077)\end{array}$ & $\begin{array}{c}-0.0620^{* * *} \\
(0.0064)\end{array}$ & $\begin{array}{c}-0.0615^{* * *} \\
(0.0059)\end{array}$ & $\begin{array}{c}-0.0580^{* * *} \\
(0.0066)\end{array}$ & $\begin{array}{c}-0.0606^{* * *} \\
(0.0066)\end{array}$ & $\begin{array}{c}-0.0734^{* * *} \\
(0.0099)\end{array}$ & $\begin{array}{c}-0.1011^{* * * *} \\
(0.0168)\end{array}$ \\
\hline ECG & $\begin{array}{c}0.0135^{* * *} \\
(0.0026)\end{array}$ & $\begin{array}{c}0.0140^{* *} \\
(0.0065)\end{array}$ & $\begin{array}{c}0.0149 * * * \\
(0.0029)\end{array}$ & $\begin{array}{c}0.0170^{* * *} \\
(0.0020)\end{array}$ & $\begin{array}{c}0.0168^{* * *} \\
(0.0016)\end{array}$ & $\begin{array}{c}0.0169^{* * *} \\
(0.0015)\end{array}$ & $\begin{array}{c}0.0153^{* * *} \\
(0.0017)\end{array}$ & $\begin{array}{c}0.0141^{* * *} \\
(0.0017)\end{array}$ & $\begin{array}{c}0.0140^{* * *} \\
(0.0025)\end{array}$ & $\begin{array}{c}0.0194^{* * *} \\
(0.0043)\end{array}$ \\
\hline ECD & $\begin{array}{c}0.0876^{* * *} \\
(0.0336)\end{array}$ & $\begin{array}{c}0.1723^{* *} \\
(0.0835)\end{array}$ & $\begin{array}{c}0.0935^{* *} \\
(0.0373)\end{array}$ & $\begin{array}{c}0.0598 * * \\
(0.0254)\end{array}$ & $\begin{array}{l}0.0533^{* *} \\
(0.0211)\end{array}$ & $\begin{array}{l}0.0367^{*} \\
(0.0194)\end{array}$ & $\begin{array}{c}0.0161 \\
(0.0220)\end{array}$ & $\begin{array}{c}0.0252 \\
(0.0220)\end{array}$ & $\begin{array}{c}0.0051 \\
(0.0327)\end{array}$ & $\begin{array}{l}-0.0026 \\
(0.0558)\end{array}$ \\
\hline FID & $\begin{array}{c}0.0011 \\
(0.0009)\end{array}$ & $\begin{array}{l}-0.0008 \\
(0.0021)\end{array}$ & $\begin{array}{c}0.0005 \\
(0.0010)\end{array}$ & $\begin{array}{l}0.0012 * \\
(0.0007)\end{array}$ & $\begin{array}{l}0.0011 * \\
(0.0005)\end{array}$ & $\begin{array}{l}0.0009 * \\
(0.0005)\end{array}$ & $\begin{array}{c}0.0012 * * \\
(0.0006)\end{array}$ & $\begin{array}{l}0.0009 * \\
(0.0006)\end{array}$ & $\begin{array}{c}0.0013 \\
(0.0008)\end{array}$ & $\begin{array}{c}0.0028^{* *} \\
(0.0014)\end{array}$ \\
\hline Constant & $\begin{array}{c}0.3711 \\
(0.3033)\end{array}$ & $\begin{array}{l}-0.8437 \\
(0.7532)\end{array}$ & $\begin{array}{l}-0.4507 \\
(0.3365)\end{array}$ & $\begin{array}{l}-0.1864 \\
(0.2290)\end{array}$ & $\begin{array}{c}0.0256 \\
(0.1905)\end{array}$ & $\begin{array}{l}0.2941 \text { * } \\
(0.1753)\end{array}$ & $\begin{array}{c}0.6170^{* * *} \\
(0.1982)\end{array}$ & $\begin{array}{c}0.6728^{* * *} \\
(0.1984)\end{array}$ & $\begin{array}{c}1.1257^{* * *} \\
(0.2946)\end{array}$ & $\begin{array}{c}1.6624 * * * \\
(0.5031)\end{array}$ \\
\hline $\begin{array}{l}\text { R2/Pseudo } \\
\text { R2 }\end{array}$ & 0.1324 & 0.0573 & 0.0455 & 0.0473 & 0.0576 & 0.0726 & 0.0888 & 0.1086 & 0.1265 & 0.1507 \\
\hline N. of cases & 7730 & 7730 & 7730 & 7730 & 7730 & 7730 & 7730 & 7730 & 7730 & 7730 \\
\hline
\end{tabular}

Notes: Bootstrapped SEs (1000 reps) are shown in parentheses. ${ }^{* * *}$ Stands for significant coefficient at $1 \%$ level, ${ }^{* *}$ at $5 \%$, and ${ }^{*}$ at $10 \%$; LEV stands for leverage; AGE the firm age; SIZ the firm size; LIQ the liquidity; LAP the labour productivity; ECG the economic growth; ECD the economic development; FID the financial development.

To test the robustness of our findings, we used another quantile model, namely simultaneous quantile regression. The results presented in the Appendix A confirm the previous findings of the main estimations.

In terms of practical implications, our results provide empirical evidence for the need to develop new public policies that provide access to relevant alternative sources of financing for gazelles in order to reduce their reliance on debt. For example, institutional investors (investment funds, insurance companies, and pension funds) could represent a source of financing as "they are patient investors and require highly diversified portfolios" ([6], p. 207). In addition, public policies should focus on the development of the venture capital market which is vital for small, growing, early-stage European businesses.

\section{Conclusions}

Although there is a wealth of literature on the effect of leverage on firm growth, there is no study on the effects of financing decisions on the growth of a highly desired set of firms (gazelles) and the mediating role of fiscal policy. Contrary to the previous studies, we employ a panel data quantile regression approach to test this relationship on a sample of gazelles from emerging Europe for the period from 2006 to 2014. The main advantage of the $Q R$ methodology is that it allows for a more detailed picture of the relationship between leverage and firm growth. Furthermore, the period of study is of particular interest because it allows us to assess the effects of economic and financial development on fiscal policy on firm growth, respectively.

Our results provide evidence of a non-linear relationship between leverage and firm growth. We found a negative relationship between leverage and sales growth for firms in the lower quantiles of the distribution. According to Myers [42], when leverage is high, gazelles are more likely to forgo positive net present value projects because the payoff from these investments will eventually go to banks, and thus, they are not able to support their sales growth. We also found that the negative effect is higher for the gazelles located in countries with lower corporate income effective tax rates. By contrast, this relationship became positive for firms in the higher quantiles of the growth distribution.

These findings have the potential to reconcile the ambiguity in the earlier studies on this topic, being particularly important in a region where leverage is higher compared with the developed economies and many governments cut the profit taxes in order to attract foreign investors. Our results contribute to the scant literature on the role of financing decisions on gazelles' performance. In terms of practical implications, our empirical evidence may be of interest to SMEs operating within a bank-based financial system and 
also for policymakers. For example, policymakers need to develop public programs to solve issues associated with difficult access to finance. Furthermore, in these particular countries with bank-based systems, public authorities have to support the development of alternatives sources of financing such as risk capital and crowdfunding.

Author Contributions: All authors were involved in the documentation phase, in choosing the research methodology, in data analysis, as well as in result analysis and discussions. All authors participated in the manuscript preparation and have approved the submitted manuscript. All authors have read and agreed to the published version of the manuscript.

Funding: This research received no external funding.

Institutional Review Board Statement: Not applicable.

Informed Consent Statement: Not applicable.

Data Availability Statement: Data available on request due to restrictions.

Conflicts of Interest: The authors declare no conflict of interest.

\section{Appendix A. Robustness Check}

\begin{tabular}{|c|c|c|c|c|c|c|c|c|c|c|}
\hline & OLS & 10th $Q$ & 20th $Q$ & 30th Q & 40th Q & 50th $Q$ & 60th Q & 70th Q & 80th Q & 90th Q \\
\hline LEV & $\begin{array}{c}-0.031 \\
(0.017)\end{array}$ & $\begin{array}{c}-0.177^{* * *} \\
(0.058)\end{array}$ & $\begin{array}{c}-0.064^{* * *} \\
(0.021)\end{array}$ & $\begin{array}{l}-0.017 \\
(0.015)\end{array}$ & $\begin{array}{c}0.000 \\
(0.010)\end{array}$ & $\begin{array}{c}0.011 \\
(0.013)\end{array}$ & $\begin{array}{c}0.021 \\
(0.015)\end{array}$ & $\begin{array}{c}0.037 \\
(0.024)\end{array}$ & $\begin{array}{c}0.075^{* * *} \\
(0.022)\end{array}$ & $\begin{array}{c}0.148^{* * *} \\
(0.044)\end{array}$ \\
\hline AGE & $\begin{array}{c}-0.442 * * * \\
(0.016)\end{array}$ & $\begin{array}{c}-0.321 * * * \\
(0.030)\end{array}$ & $\begin{array}{c}-0.244^{* * *} \\
(0.014)\end{array}$ & $\begin{array}{c}-0.231 * * * \\
(0.006)\end{array}$ & $\begin{array}{c}-0.255^{* * *} \\
(0.016)\end{array}$ & $\begin{array}{c}-0.285 * * * \\
(0.013)\end{array}$ & $\begin{array}{c}-0.321 * * * \\
(0.012)\end{array}$ & $\begin{array}{c}-0.351 * * * \\
(0.008)\end{array}$ & $\begin{array}{c}-0.419 * * * \\
(0.020)\end{array}$ & $\begin{array}{c}-0.547^{* * *} \\
(0.017)\end{array}$ \\
\hline SIZ & $\begin{array}{c}0.086^{* * *} \\
(0.006)\end{array}$ & $\begin{array}{c}0.077^{* * *} \\
(0.017)\end{array}$ & $\begin{array}{c}0.058^{* * *} \\
(0.005)\end{array}$ & $\begin{array}{c}0.046^{* * *} \\
(0.003)\end{array}$ & $\begin{array}{c}0.042^{* * *} \\
(0.004)\end{array}$ & $\begin{array}{c}0.039 * * * \\
(0.003)\end{array}$ & $\begin{array}{c}0.042^{* * *} \\
(0.005)\end{array}$ & $\begin{array}{c}0.042^{* * *} \\
(0.003)\end{array}$ & $\begin{array}{c}0.043^{* * *} \\
(0.006)\end{array}$ & $\begin{array}{c}0.062^{* * *} \\
(0.008)\end{array}$ \\
\hline LIQ & $\begin{array}{c}-0.006^{* *} \\
(0.003)\end{array}$ & $\begin{array}{c}-0.030 * * * \\
(0.010)\end{array}$ & $\begin{array}{c}-0.008^{* *} \\
(0.004)\end{array}$ & $\begin{array}{l}-0.003 \\
(0.003)\end{array}$ & $\begin{array}{l}-0.002 \\
(0.001)\end{array}$ & $\begin{array}{l}-0.001 \\
(0.002)\end{array}$ & $\begin{array}{l}-0.001 \\
(0.002)\end{array}$ & $\begin{array}{l}-0.001 \\
(0.002)\end{array}$ & $\begin{array}{c}0.001 \\
(0.002)\end{array}$ & $\begin{array}{c}0.005 \\
(0.005)\end{array}$ \\
\hline LAP & $\begin{array}{c}-0.176^{* * *} \\
(0.008)\end{array}$ & $\begin{array}{c}-0.112^{* * *} \\
(0.020)\end{array}$ & $\begin{array}{c}-0.075^{* * *} \\
(0.009)\end{array}$ & $\begin{array}{c}-0.063^{* * *} \\
(0.005)\end{array}$ & $\begin{array}{c}-0.062^{* * *} \\
(0.005)\end{array}$ & $\begin{array}{c}-0.067^{* * *} \\
(0.005)\end{array}$ & $\begin{array}{c}-0.073^{* * *} \\
(0.007)\end{array}$ & $\begin{array}{c}-0.080^{* * *} \\
(0.006)\end{array}$ & $\begin{array}{c}-0.100^{* * *} \\
(0.008)\end{array}$ & $\begin{array}{c}-0.153^{* * *} \\
(0.014)\end{array}$ \\
\hline ECG & $\begin{array}{c}0.014^{* * *} \\
(0.002)\end{array}$ & $\begin{array}{c}0.014^{* * *} \\
(0.005)\end{array}$ & $\begin{array}{c}0.015^{* * *} \\
(0.002)\end{array}$ & $\begin{array}{c}0.017^{* * *} \\
(0.001)\end{array}$ & $\begin{array}{c}0.017^{* * *} \\
(0.001)\end{array}$ & $\begin{array}{c}0.017^{* * *} \\
(0.001)\end{array}$ & $\begin{array}{c}0.015^{* * *} \\
(0.001)\end{array}$ & $\begin{array}{c}0.015^{* * *} \\
(0.001)\end{array}$ & $\begin{array}{c}0.016^{* * *} \\
(0.002)\end{array}$ & $\begin{array}{c}0.019^{* * *} \\
(0.003)\end{array}$ \\
\hline ECD & $\begin{array}{c}0.075^{* * *} \\
(0.016)\end{array}$ & $\begin{array}{c}0.177^{* * *} \\
(0.023)\end{array}$ & $\begin{array}{c}0.094^{* * *} \\
(0.015)\end{array}$ & $\begin{array}{c}0.058^{* * *} \\
(0.007)\end{array}$ & $\begin{array}{c}0.037^{* * *} \\
(0.010)\end{array}$ & $\begin{array}{c}0.014 \\
(0.010)\end{array}$ & $\begin{array}{c}0.004 \\
(0.012)\end{array}$ & $\begin{array}{c}-0.020^{* *} \\
(0.009)\end{array}$ & $\begin{array}{c}-0.035^{* * *} \\
(0.010)\end{array}$ & $\begin{array}{c}-0.045^{* *} \\
(0.021)\end{array}$ \\
\hline FID & $\begin{array}{c}0.002 * * \\
(0.001)\end{array}$ & $\begin{array}{c}0.000 \\
(0.002)\end{array}$ & $\begin{array}{c}0.001 \\
(0.001)\end{array}$ & $\begin{array}{c}0.001 \\
(0.000)\end{array}$ & $\begin{array}{c}0.001^{* * *} \\
(0.000)\end{array}$ & $\begin{array}{c}0.001^{* * *} \\
(0.000)\end{array}$ & $\begin{array}{c}0.001^{* * *} \\
(0.000)\end{array}$ & $\begin{array}{c}0.001^{* * *} \\
(0.000)\end{array}$ & $\begin{array}{c}0.001 * * * \\
(0.000)\end{array}$ & $\begin{array}{c}0.002^{* * *} \\
(0.001)\end{array}$ \\
\hline Constant & $\begin{array}{c}0.622 * * * \\
(0.169)\end{array}$ & $\begin{array}{c}-1.348^{* * *} \\
(0.363)\end{array}$ & $\begin{array}{c}-0.692 * * * \\
(0.165)\end{array}$ & $\begin{array}{c}-0.272^{* * *} \\
(0.066)\end{array}$ & $\begin{array}{c}0.059 \\
(0.087)\end{array}$ & $\begin{array}{c}0.483^{* * *} \\
(0.114)\end{array}$ & $\begin{array}{c}0.724^{* * *} \\
(0.125)\end{array}$ & $\begin{array}{c}1.144^{* * *} \\
(0.100)\end{array}$ & $\begin{array}{c}1.663 * * * \\
(0.112)\end{array}$ & $\begin{array}{c}2.366^{* * *} \\
(0.285)\end{array}$ \\
\hline $\begin{array}{l}\text { R2/Pseudo } \\
\text { R2 }\end{array}$ & 0.1580 & 0.0543 & 0.0582 & 0.0594 & 0.0669 & 0.0815 & 0.0983 & 0.1196 & 0.1433 & 0.1845 \\
\hline N. of cases & 7730 & 7730 & 7730 & 7730 & 7730 & 7730 & 7730 & 7730 & 7730 & 7730 \\
\hline
\end{tabular}

Notes: Bootstrapped SEs (1000 reps) are shown in parentheses. ${ }^{* * *}$ Stands for significant coefficient at $1 \%$ level, ${ }^{* *}$ at $5 \%$ and ${ }^{*}$ at $10 \%$.; LEV stands for leverage; AGE the firm age; SIZ the firm size; LIQ the liquidity; LAP the labour productivity; ECG the economic growth; ECD the economic development; FID the financial development.

\section{References}

1. European Union. Europe 2020: A Strategy for Smart, Sustainable and Inclusive Growth-Communication from the Commission. European Union. 2010. Available online: http:/ / eur-lex.europa.eu/legalcontent/en/ALL/?uri=CELEX\%3A52010DC2020 (accessed on 20 June 2020).

2. OECD. An International Benchmarking Analysis of Public Programmes for High Growth Firms; OECD: Paris, France, 2013. Available online: http:/ / www.oecd.org/cfe/leed/OECDDBA\%20HGF\%20PROGRAMME\%20REPORT_SECOND\%20FINAL\%20DRAFT\% 20(2).pdf (accessed on 8 May 2020).

3. Goswami, A.G.; Medvedev, D.; Olafsen, E. High-Growth Firms. Facts, Fiction, and Policy Options for Emerging Economies, The World Bank, Washington; World Bank: Washington, DC, USA, 2018. [CrossRef]

4. Eurostat-OECD. Eurostat-OECD Manual on Business Demography Statistics. 2007. Available online: http://www.oecd.org/std/ 39974460.pdf (accessed on 16 June 2016).

5. Brown, R.; Mawson, S.; Mason, C. Myth-busting and entrepreneurship policy: The case of high growth firms. Entrep. Reg. Dev. 2017, 29, 414-443. [CrossRef]

6. European Investment Bank. EIB Investment Report 2018/2019: Retooling Europe's Economy. 2018. Available online: http: //www.eib.org/en/infocentre/publications/all/investment-report-2018.htm (accessed on 10 April 2020).

7. Henrekson, M.; Johansson, D. Gazelles as job creators: A survey and interpretation of the evidence. Small Bus. Econ. 2010, 35, 227-244. [CrossRef] 
8. Cuaresma, J.C.; Oberhofer, H.; Vincelette, G.A. Institutional barriers and job creation in Central and Eastern Europe. IZA J. Eur. Labor Stud. 2014, 3. [CrossRef]

9. Coad, A. The Growth of Firms: A Survey of Theories and Empirical Evidence; Edward Elgar: Cheltenham, UK, 2009.

10. Stam, E.; van Stel, A. Types of entrepreneurship and economic growth. In Innovation, Entrepreneurship and Economic Development; Goedhuys, M., Naude, W., Szirmai, E., Eds.; Oxford University Press: Oxford, UK, 2011; pp. 78-95.

11. Demir, R.; Wennberg, K.; McKelvie, A. The strategic management of high-growth firms: A review and theoretical conceptualization. Long Range Plan. 2017, 50, 431-456. [CrossRef]

12. Yan, D.; Kong, Y.; Ren, X.; Shi, Y.; Chiang, S. The determinants of urban sustainability in Chinese resource-based cities: A panel quantile regression approach. Sci. Total Environ. 2019, 686, 1210-1219. [CrossRef] [PubMed]

13. Dong, K.; Dong, X.; Ren, X. Can expanding natural gas infrastructure mitigate CO2 emissions? Analysis of heterogeneous and mediation effects for China. Energy Econ. 2020, 90, 104830. [CrossRef]

14. Yan, D.; Ren, X.; Kong, Y.; Ye, B.; Liao, Z. The heterogeneous effects of socioeconomic determinants on PM2.5 concentrations using a two-step panel quantile regression. Appl. Energy 2020, 272, 115246. [CrossRef]

15. Cheng, C.; Ren, X.; Dong, K.; Dong, X.; Wang, Z. How does technological innovation mitigate CO2 emissions in OECD countries? Heterogeneous analysis using panel quantile regression. J. Environ. Manag. 2021, 280, 111818. [CrossRef]

16. Dimelis, S.; Giotopoulos, I.; Louri, H. Can firms grow without credit? A quantile panel analysis in the Euro area. J. Ind. Compet. Trade 2017, 17, 153-183. [CrossRef]

17. Coricelli, F.; Driffield, N.; Pal, S.; Roland, I. When does leverage hurt productivity growth? A firm-level analysis. J. Int. Money Financ. 2012, 31, 1674-1694. [CrossRef]

18. Heshmati, H. On the growth of micro and small firms: Evidence from Sweden. Small Bus. Econ. 2001, 17, 213-228. [CrossRef]

19. Honjo, Y.; Harada, N. SME policy, financial structure and firm growth: Evidence from Japan. Small Bus. Econ. 2006, 27, 289-300. [CrossRef]

20. Mateev, M.; Anastasov, Y. Determinants of small and medium sized fast growing enterprises in Central and Eastern Europe: A panel data analysis. Financ. Theory Pract. 2010, 34, 269-295.

21. Lopez-Garcia, P.; Puente, S. What makes a high growth firm? A dynamic probit analysis using Spanish firm-level data. Small Bus. Econ. 2012, 39, 1029-1041. [CrossRef]

22. Anton, S.G. Leverage and firm growth: An empirical investigation of gazelles from emerging Europe. Int. Entrep. Manag. J. 2019, 15, 209-232. [CrossRef]

23. Huynh, K.; Petrunia, R. Age effects, leverage, and firm growth. J. Econ. Dyn. Control 2010, 34, 1003-1013. [CrossRef]

24. Cole, R.A.; Sokolyk, T. Debt financing, survival, and growth of start-up firms. J. Corp. Financ. 2018, 50, 609-625. [CrossRef]

25. Lang, L.; Ofek, E.; Stulz, R.M. Leverage, investment, and firm growth. J. Financ. Econ. 1996, 40, 3-29. [CrossRef]

26. Le, T.P.V.; Phan, T.B.N. Capital structure and firm performance: Empirical evidence from a small transition country. Res. Int. Bus. Financ. 2017, 42, 710-726. [CrossRef]

27. Hashi, I.; Krasniqi, B.A. Entrepreneurship and SME growth: Evidence from advanced and laggard transition economies. Int. J. Entrep. Behav. Res. 2011, 17, 456-487. [CrossRef]

28. Botrić, V.; Božić, L. Access to finance: Innovative firms' perceptions in post-transition EU members. Econ. Manag. 2017, 20, 129-143. [CrossRef]

29. Dinh, H.; Mavridis, D.; Nguyen, H. The Binding Constraint on Firms' Growth in Developing Countries; The World Bank, Policy Research Working Paper No. 5485; World Bank: Washington, DC, USA, 2010.

30. Damijan, J. Corporate NPL Portfolios in CESEE Countries: How Corporate Leverage and Debt Spillovers Affect Firm Performance; Working Paper WP 191; European Bank for Reconstruction and Development: London, UK, 2016.

31. Pirtea, M.; Nicolescu, C.; Boţoc, C. Do Romanian companies follow pecking order financing? Econ. Comput. Econ. Cybern. Stud. Res. 2014, 48, 1-15.

32. Botta, M. Financial crises, debt overhang, and firm growth in transition economies. Appl. Econ. 2020, 52, 4333-4350. [CrossRef]

33. Davidsson, P.; Wiklund, J. Conceptual and empirical challenges in the study of firm growth. In Entrepreneurship and the Growth of Firms; Davidsson, P., Delmar, F., Wiklund, J., Eds.; Edward Elgar Publishing: Cheltenham, UK, 2006; pp. 39-61.

34. Buchinsky, M. Changes in the US wage structure 1963-1987: Application of quantile regression. Econom. J. Econom. Soc. 1994, $62,405-458$.

35. Coad, A.; Rao, R. Innovation and firm growth in high-tech sectors: A quantile regression approach. Res. Policy 2008, 37, 633-648. [CrossRef]

36. Ahn, S.; Yoon, J.; Kim, Y. The innovation activities of small and medium-sized enterprises and their growth: Quantile regression analysis and structural equation modelling. J. Technol. Transf. 2018, 43, 316-342. [CrossRef]

37. Bianchini, S.; Pellegrino, G.; Tamagni, F. Innovation complementarities and firm growth. Ind. Corp. Chang. 2018, 27, 657-676. [CrossRef]

38. Distante, R.; Petrella, I.; Santoro, E. Gibrat's law and quantile regressions: An application to firm growth. Econ. Lett. 2018, 164, 5-9. [CrossRef]

39. Herstad, S.J. Product innovation and employment growth at the firm level: A quantile regression approach to inter-industry differences. Appl. Econ. Lett. 2018, 25, 1062-1065. [CrossRef]

40. Koenker, R.; Hallock, K. Quantile regression: An introduction. J. Econ. Perspect. 2001, 15, 143-156. [CrossRef] 
41. Hart, O.; Moore, J. Debt and seniority: An analysis of the role of hard claims in constraining management. Am. Econ. Rev. 1995, 85, 567-585.

42. Myers, S.C. Determinants of corporate borrowing. J. Financ. Econ. 1977, 5, 147-175. [CrossRef] 